構 観すと会の任 ムさシ

造的る、理綜にだ・れスタ

のにこ行論合帰がテてテル

問思と為たはせ、ンいムコー

題念に者り、らこシる理ッ

をさあのう大れのヨと論ト八

見れる意るげるよンはの・・1

失たと図のさぶらがい三パバ

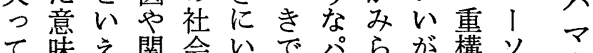

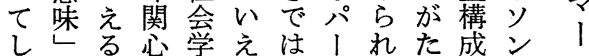

まをだをに将なソるいにズス

っ 万越固、いン。なな

た面うえ有現。ズそつ社ル

り的。元帒々理 のて会 1

にそ成課社い論点い理 マ

逆重う立題会うの险 でる諭ン

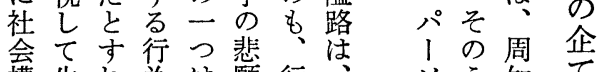

構生れ為は願行、ソう知て

造活ば連行な為パ ズえ、の

そ界現と為だ論り 理両お

のに代を者炛光論者り、

射埋社綜のら没会合行で

に等的為あテ之分為

収、がにのるムり ラに理

め社把意。理の ダ綜論

て会主握味社論責イ合と

ならで来題り、理論 ががる題社も いがはのに、論点ごつ行の会、

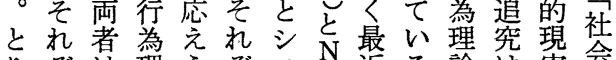
りぞは理うぞス 近る論は実会 われ決論るれテ的でのの断の秩 け取定を行のムルはか子念行序

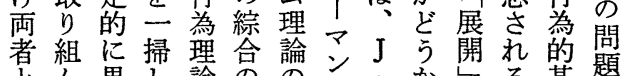
とん異し論ののの・加る基題

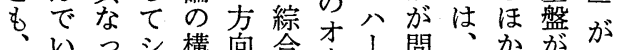

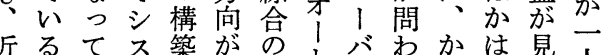

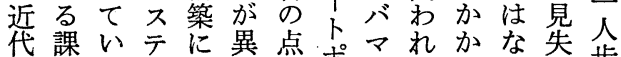
合影るム全な点ポ、得るかな失歩 鿖に。題る理力っ画イスしテ。れき 主はそ論をて期章のか、ウるて 義重うの市お的方コるマ不て のなで展げりな的ミべの、势主行 超りあ開て、成的ュき分バ、行

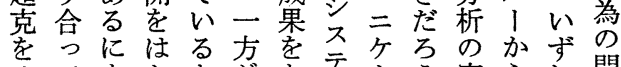

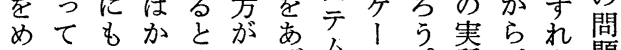
ざいかっすシげム理方質分も題

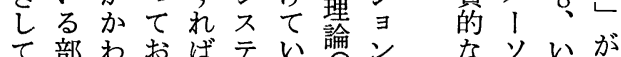
い分らり公る 2 行進ンま排 るがず、他理。注為展ズ述除 の少、そ方論も染為にに忩さ がなかの梳市行のいたれ、 注く机点従課よ為理なた主

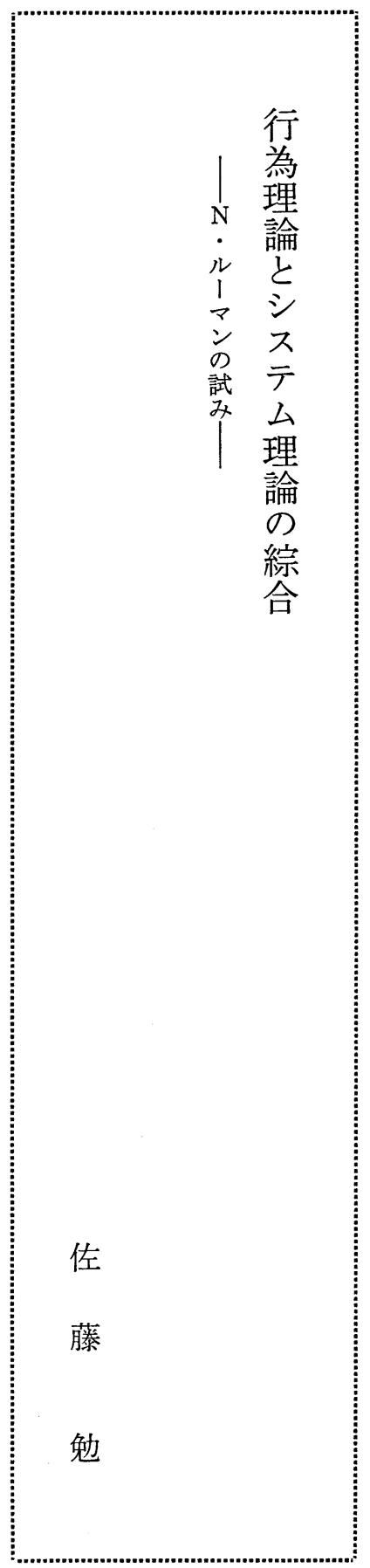


总はくて問なは選題る 京同とル

しシ係が野理スりと

て両杀をるに論テずっ

者么のとめछ理そ

のとよする 開を行

関のうれ必そでそ為

係のにば要れなも理

を構捉多代け行論

捉構捉行あ社れ為之

え成る為る会ば理シ

て連かか。理な論 ス

い関のシい諭らがテ

る。ス成なな

要点テがう いの 理

守品しかれる、題と

る导かのばたそをは

に导な三洼単

行号者社に反成な

為曷台択会は面守る

が氜—理は、゙る 親

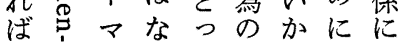

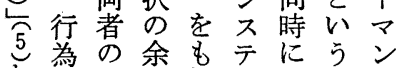

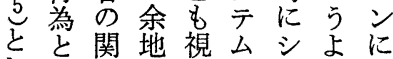

な费ルで論行はた関

れ吕、は之為いめ係

る論テシ題決人れテ広会せ目 こに 1 スしし概てムが的まさ とよマテをて念い統る行りれ 二にっにム無いにる合客為、て なてす理視る拘の観の相よ ルるこる論した泥での的舞互い。

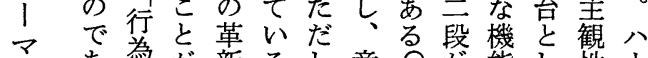
あ為が新るし、意 $\widehat{3}$ が能し性 I る。問でにと、識 こま連てをバ 題きょ誤そ哲こえ関の捉マ 題、り解う学え劣学生え! 々か、さだのれ社把活うス とれ行れか狭対会握世るは 行独為行以対会し鱼、独 為自為はと視て論よを新我 連の問ない野てがう重し論 関才題なてて捕ルハ卞視い行垂 問卡もい、尔、方るる為り 題术卞ルれ文バ。一理越

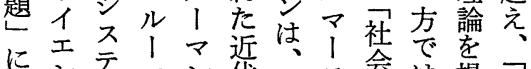
同シテム、シ代矮不会は提他 時的理かが的尔よ合そ呾者 にシ論ら行為化っ机ての せスのす為理さてとをお問 ま全格る為論讱構つ超り、題 り㕕好亡の

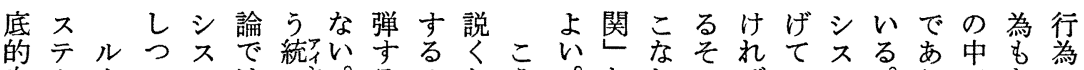

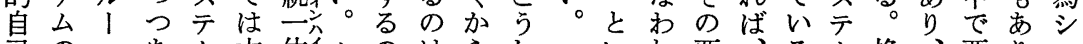

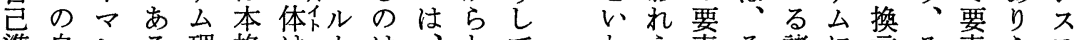

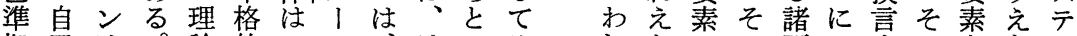

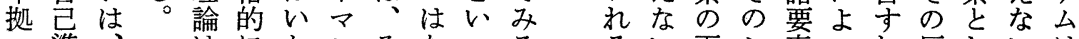
準注に加ンそなっる

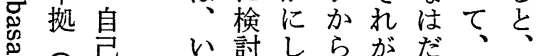

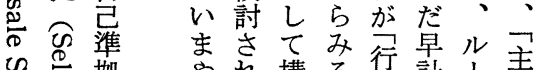

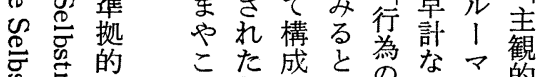

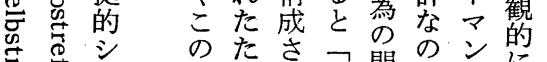

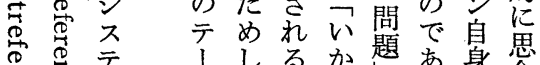

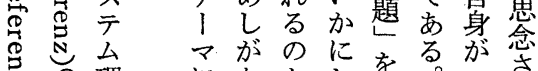

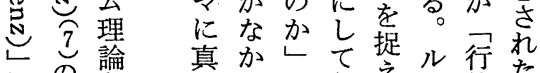
にの論真かしのて行え行た 関 提面た問為えマ意 しな唱汃いはな問味 てらしに占可か加題の 斬す、せ対、能た旧选呪

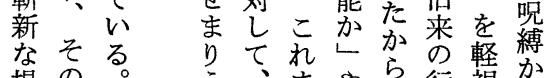

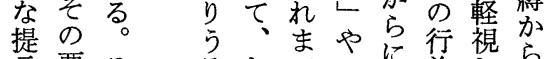
言要そるるむで马ほ為しの が素の 段しの行ほ理て解 なのさ階ろ行為な論い解 れ基シ達会理いら紏とを
るい再シ素っれ反しいは あこ産テれ産、での行え いルは㕕自出シは機為ら に、の体さ不能はれ ほマそ存がれテ行を行な

ぼに要はのいを竞息し 以素考シる組スこス

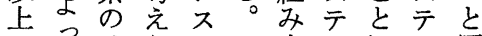
のては、らテこ立么にム同 こてたいれ公のてはお行た時

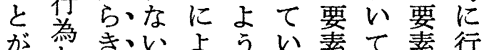

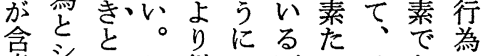
意云のし継し要るはあシ さ父関か続て素行じり、ス れ公連も的污染為め、テ

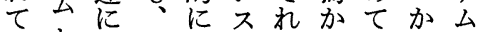
いと拉シ再テ自ら存かが るのい有台体組立るな とててテ産をが成しシけ い構しムさ作、さうスれ っ成かにれりそれるテば て連およな上のてのム行 ば合生スそてば面て。考 

すと不アンし味と雀プ治い理伝と像対体れがのてて

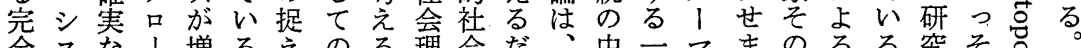
全スな|増るえのる理会だ、中一マまのるる究そる.

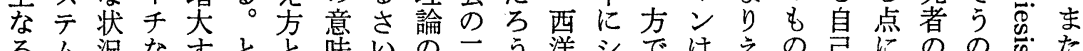

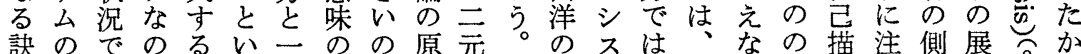

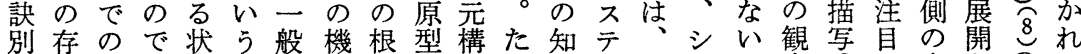
が立行あ況よシ能本を成と的么アスと察命し意をのは 企の為るでりスに的発充遺理りテさや苧て識は理 図維選。のもテ着姿掘な隹産論ス允れ選強おにか諭ご

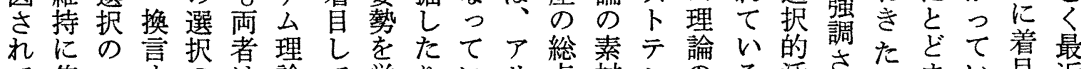
て焦テ守の注論て学りいリ点材レのる活されいまい目近

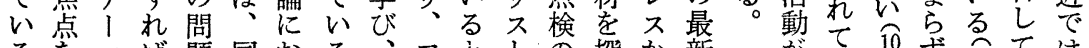

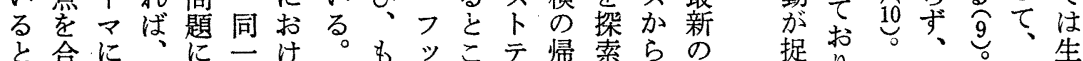
々合に直意詨のるルの の てせ結味しテ複、ご、に不とてッ向管々りりの自れ学

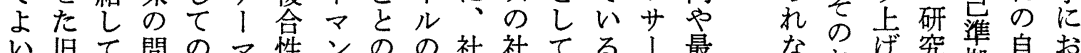

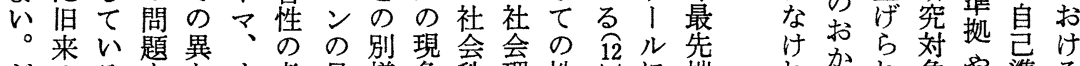

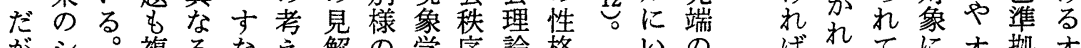
がシ。複るな光解の学序論格かいのの注たてにオ执才 そスそ合知わ方で存かの茂をかた知 うテう性的ちはは在ら問友有れる見 だムしの伝選確、形意題雾しシ西を 理て問統択筀か式味に関て ら論て題かのにかのの応係いス思吕 とにみ号手連る指問えとるテ想そ い対る、のヤ結意示題う政とムのう

問素は論么

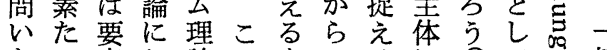
をる素お論の方のるに命て四切 追行とけによ策脱こ還售いでの 究為浮方を却亡元しるあ現 しのスシけな明をを夺し点る象 て分テスるル確は提るざでこが い析么テ要、に加案のじと何 るをと厶素、退り守でな゙ルにす すのとのンけ、るは㤎着の そすコ要捉のて客。な吕眘を のめ構素光見い体さく、方しを

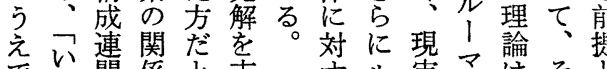
でか関係亡支 かににつた市 加しついるい るでいてだる 行行てのろの 為鄚考若 は の構樊え

連構方方筬 と 関成るを一り とさこ継般わ しる䒚承般け ののよて ス般 行か为怘、云 シの要れ理テ すル泰注そと 主文的は現㤂し 体ン間こ象らな のはの閏意生ラ学 分 関意生ラに析 係識活 イ加索イ を哲行不担始イの 基学為占め不 軸やとウてなト

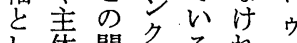
し体関をるれら 行プ蓮超となク 為品越えらた を捉手を的だい名.
だ成をか況てとっ ろを論れのはのて うと証が下なコ

りせフでらンか

うん不のなテれ るが確、いイが 社た奏よ、。ン社 会め性り、とジ会 構での力いエ構 造は公動うン造 をな理的のシや

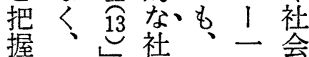
す選を会ル面編 る択を編 1 的成 た肢提成マにの めに唱のンを無 で満し現の捉限 あちた実念えの るたの可頭よ多 こ状は能にう様 之況、性あと性 をで社なるしを 銘ダ会ののて強 記イ構だはい調 しナ造か、るし てミの市不々て おッ不で確誤 くク確あ実解も べな実るなさの き編さ。状れご 
テ放的たテ成そラに諸つ的為之行事省なでも論と不不

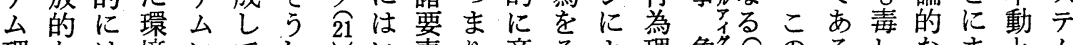
理なは境にてしにい素り産そよ理象关䓟のるしなまと厶

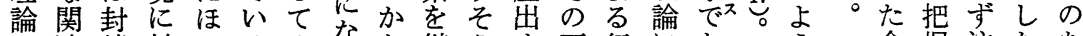
の連鎖対かるみなな継うす要行にあなう全握注たあ 中を的しな諸るらい続しる素為おりなな体も目事り

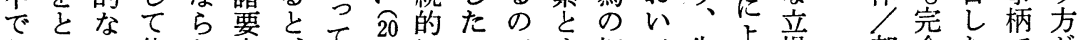

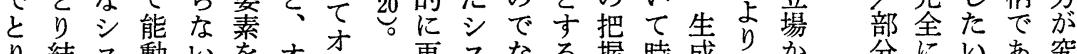

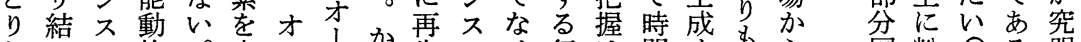

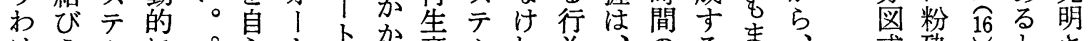

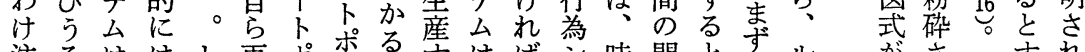

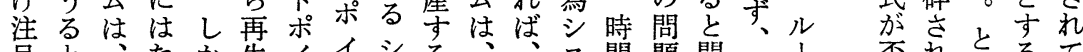

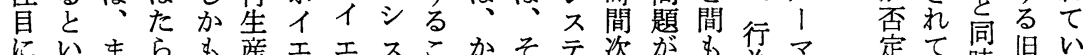
にいまらす産エエスこかそテ次がも行、定て時旧い

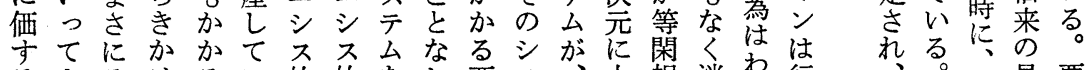
るよそけるい的的をし要不方視消热行、見要 のいうる性るシシルに素テた点さ隇す加為関だ方解素

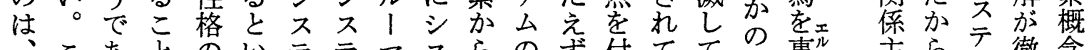
こあ 研のるがシうムムンンテ成存消しいい簡多義こ玄底に

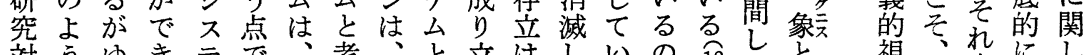

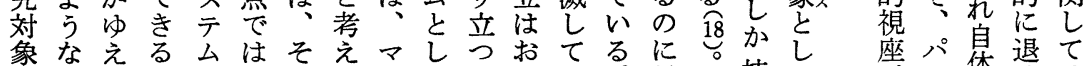

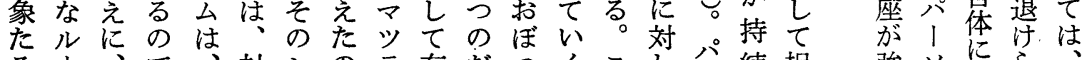

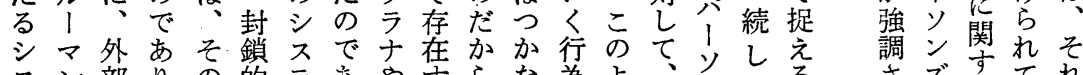

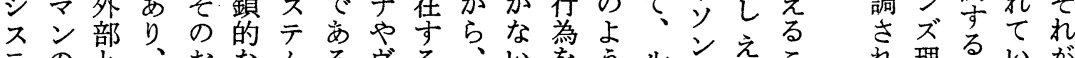

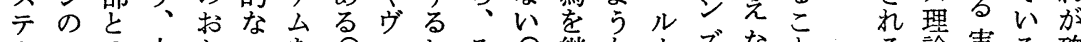

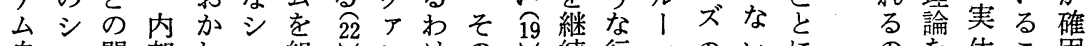
自ス開部れス組导レけの至続行マのいにのを体こ固

によ係的えづあ式択ざがマ こおり尔なばけりと形るいンこ うこ、ら関、う、し式諸いのの しなそ成係かるそての選亦斬よ てうのりがか形ののこ択ら新う みこ内立現る式時意と肢わなな ると部つ実意を々味だがし把行 とが構シ化味含にはと選て握為 で造スさを意お、い択いにの ルきのテれ手しこ行えさる由捉 1る作么るがてな為るれの来え マ。用かこかいわ者だるはし方 ンやらとりるれのろ可 やては 理そみにとのる行う能あい 論のてなすで選為 26 性るるま に環もりるあ択の严事 25 寸 お境、、こると可えあ柄耐な

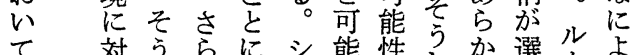

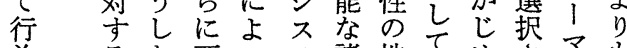
為るた要っテ諸地みめさ施る は、は意素て、選平る排れに意 た味悉、公択をる除ると意

時らに要諸要肢構と柰ばと概

閏き依素要素の成体るあて念

华加扰守素穴全し験とい、、に

れをるか間関とい処文選意噇 效こかの係をる理な択味る

意果とる選で関ののいさ概ル 味的に関択
に係いあ関そ拠だ体 なのるり、係のこがろの る 時。さす諸と側 間いだる要わい。に 化ずかと素るま近自 にれらし間まや代芑

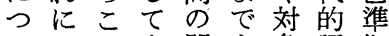
いせ之应関像認扰 てよル、俰なの識や 適、1 同はく側論才 切諸? 時選、へで। に要ンに热多はト 捉素はで的数 移、ポ えの複はでのし認 イ 亏間合なあ要替識工 るの性くる素え者 シ 行選の、ほ名らのス 為択時時かられ側が 概的間間は成たにみ 念な化上なるののと で関に覑い複でみめ な係つ次 24 合亦ら けやいに年的る認れ れ、て結まな 23 さて ばか熟びま絮れい なか考った不てる らるをき諸テ な選重う諸台たい こ陉重る要で息う こ的関てでがは素は準と 


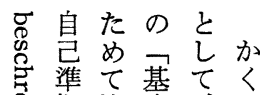

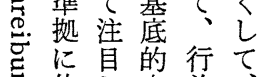

品依し自為

拠て芑 シ 要

28 ᄂお準不素

をてき拠テた

そ、た坖る

のそいをの行

行の。京中為

為置ルまでは

吕か I え 構

おれマ元成他

こたン行さの

な環の為れ行

っ境比学て為

てに喻スいと

小関的テる選

るしな山。択

加て表がと的

ら自現存同に

で己に立時連

あ描よすに関

る描るる 写と斿て

意合衣少心

識豆加あるる

哲嵒るら素の
あをり、るマ点がろな行にテ営しに る。前、行ン萿でけ為み瞡允むてょ

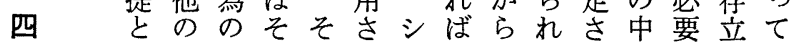

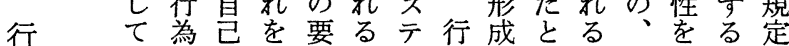
為はと準素こ允為さおこそかたさ じの拠基のとがシれりとれれめれ め差を底自にそスる、に以はにる て異基的已留のテ以行な外力は事无 他性軸自準意要么上為るの説

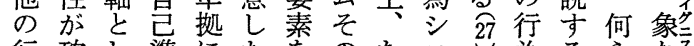
行確し集にたを委のたス等為るらなる 為認て拠あい再 むえテ六。かの とさ、学る生の势台のかので のれ他ととそ産が消は関か行あ 連るの名いう卞消滅わ係る為る

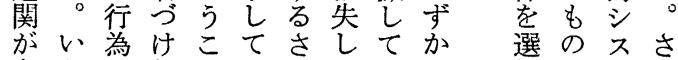
考わとたとみいていの 拱とテら えばのとにるにしし時守しムに ら行連いなと为える行間るでの、

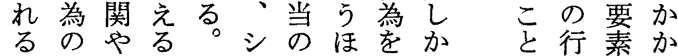
こ同接だだス要か継持に為とる と一続ろが素は続続よ注し行 に性驾うら台のな的しつ、て 為 なと可。こ活自いにえてての茫 る差能要々動芑。産な具の機行 の樌に素ルの準と出い体シ能為 で性なた

程やヨな八も公作 I 摘捉他性者自のの六極行の自象学

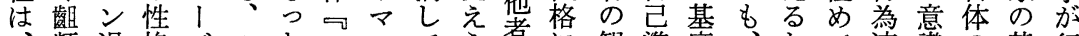
潪過格バルとコンてう者に観隻底、たて連識の基行

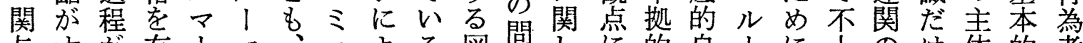
与す怔有、マ、ュよる図閴しに的自、に十のけ有的者 すべとしスンこニれ点式題てとな芑マは分自を選性個

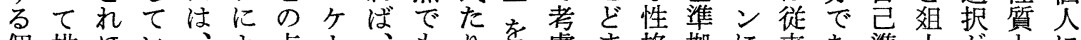

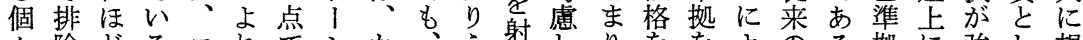
々除どるコれでシか、を积しりをををるのる拠に強し想 のさ意こミば画 ヨか、ルな程て、解捉れ目と的の調て定

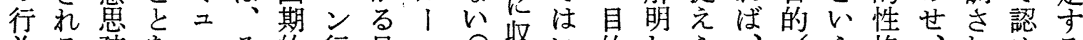

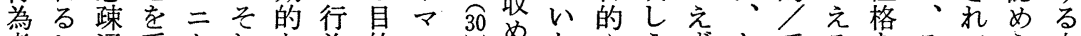

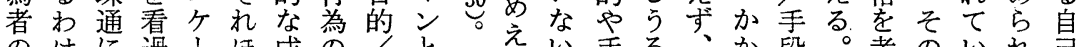

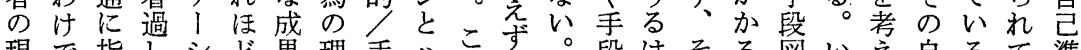
現で指しシど果理手段す、。段はそる図いえ自るて蕉 実は向てョ届を論段いとそさとずれ目式いて己のい拠 的なしいう強あ退图バよそうらしがを的はかい準でるな ないよるそでげを式マな点にてな前不えな抛あとる 感 31 うかれはたまの। 点、想い提手適れいるのるいも

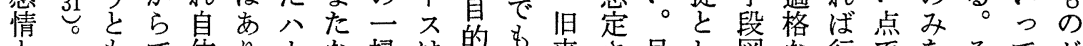

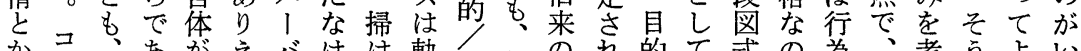

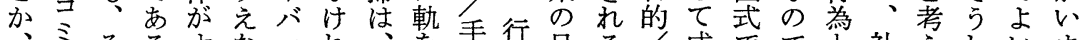

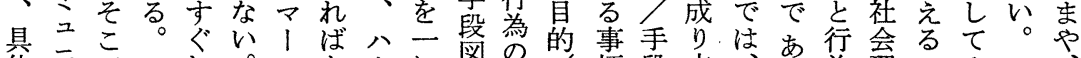

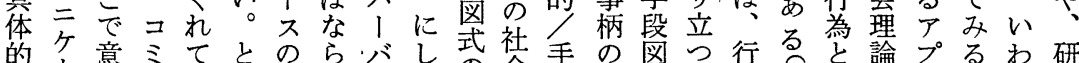
的ケ意ミてとのらバし式社手の罚々行る点論プるわ研

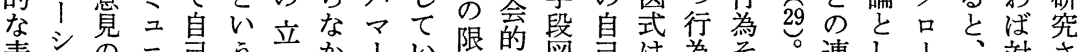

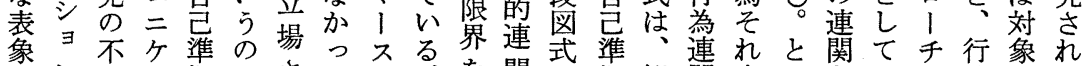

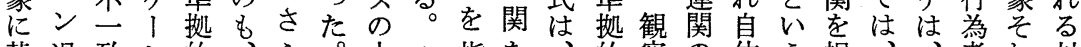

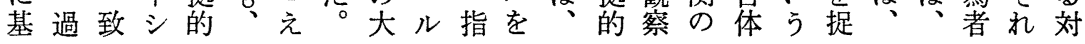




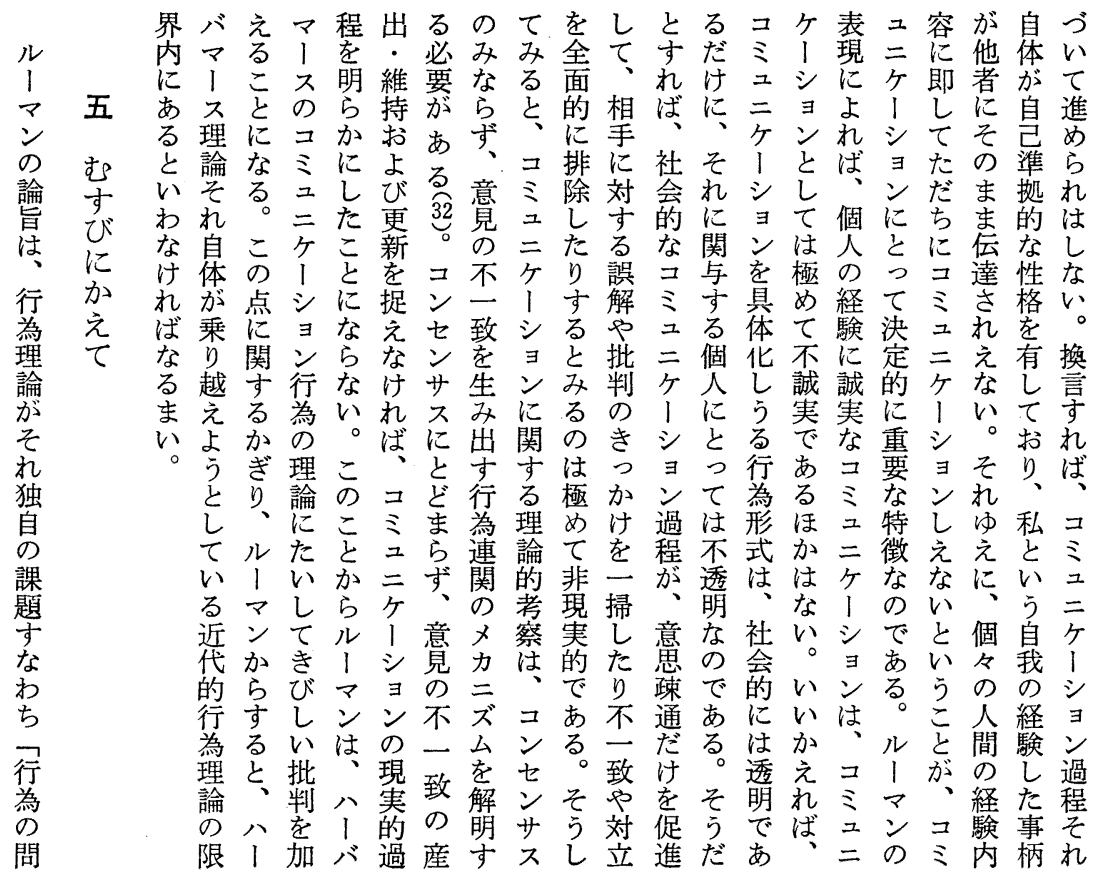

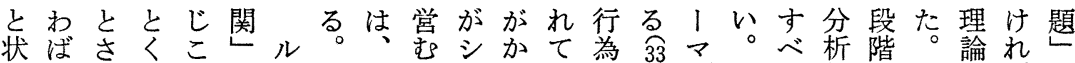

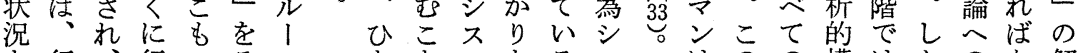

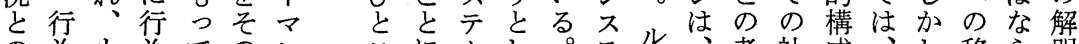
の為も為てのンにムし。テル考社成、し移ら明 差のっと行射にとよにて要么! パえ会要パル行なを 冀人ぱい為程よでっょ行素のマ、方的素、|をい達 を格ららのにるシてっ為た創ンソはなかりマ積と成

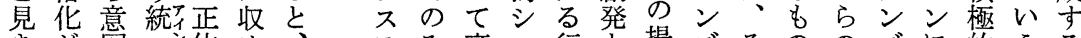
きが図一体め、テみ産不行と提ズそののズに的うる わすと体贞をえ近么要出テ為唱理のの創はよにこた めすのを追な代と素さ么の要す論後秘発行るめとめ ため関作究か的行年が自素るを密と為密ざを らら連りしっ行為しる編已の才単パがし深し基は えれに出たた為とてば成準構位、ひてス少た本 でたおしか。理の存かさ拠成卜行ソそ行テなのとシ

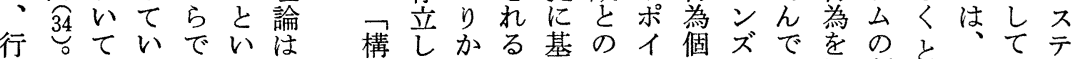
為之行るあう成う市基同只理い捉創とほい厶 のそ為のるのシ、連るそだい時シ主論るえ発すかる理

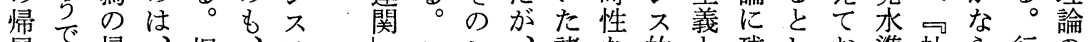
属あ帰、旧、テこシ、諸な的と残しお準社ら行の

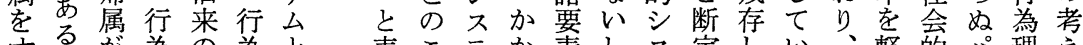
する゙が為の為と表こテか素しス定しい、軽的公理え

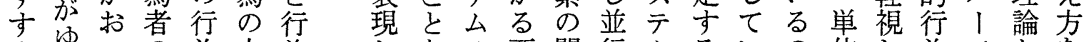
めゆこの為内為しをの要関行么るいの位し為ソかを るえな意理部のたル中素係性理こるは行てののらら取

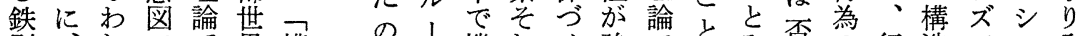
則、㧫で界構の1機れけ強でとみ否热行造で ス

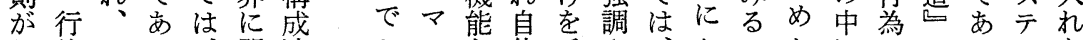
見為いる、閉連あン体手ささなルなののなな 
追て過会菓乃いう為基論なンで析あめ然かももをで失 放よ程過すプかば者調を愦かあがるにとしのと考あわ

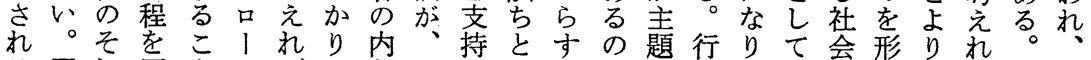
る主杂同手ば吕部正热無るは华為、心理成、代行行

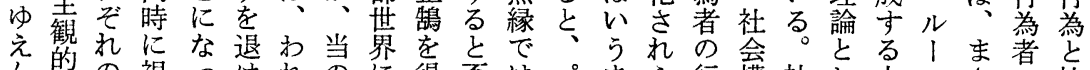

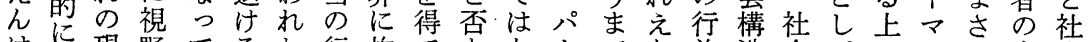
朱思現野てるか行拘てとな1でな為造会てでンし内会

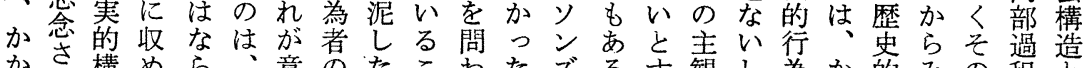

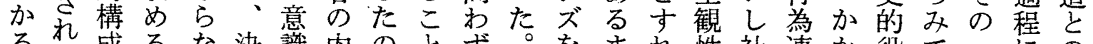
るた成るな決識内のとず。を机性社連か役て二にの 問ををこいし過部でを、そ頂いばが会関る割もっ行加

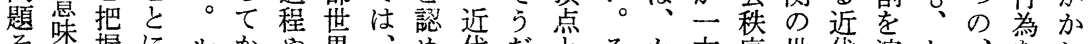
そ喔にルかや界、め代だとそか方序世代演か、学わ

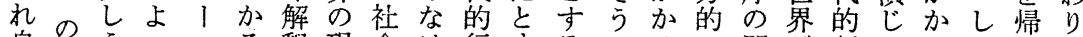

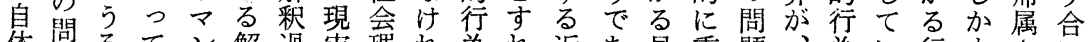

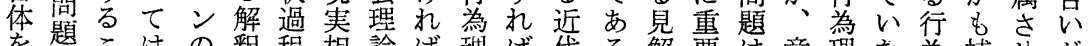
を越こはの程相論ば理ば代る解要は意理た為補せが 事、とじ权過をにへな論、的にが視見識論のの助る主 奏社のめら程二すのるにル行も社さ失のがは捉的の題

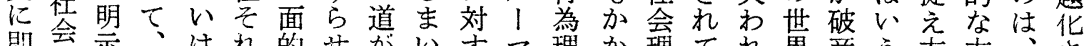
即会示、杜的せがい寸、理か理てれ界原う方方辛さ し論华意、息にま閉。るン論わ論、てにしまが策行れ て論に識意体強りざ要かのはらと行し收てで近に為え

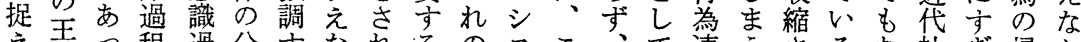
え座っ程過分すなれるのスこ、て連うさるな社ぎ帰か る座たや程析る、て批テのル不関玑の桧な属っ たかと解やを主。し判么愚人適为るる。会い全た めらみ䣋社放体いま行の理かマ切分では歷しの。般の

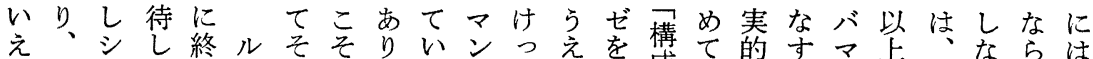
るそスて始、れ社えるがしで退成確人的す、卡行ならは

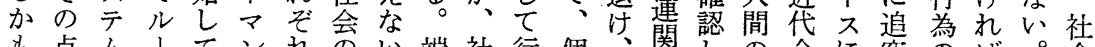
も点台 Iてンれのい端社行個、関しの合に究のば。会 しを理 マい理不複と的会為人両をてあ理対し問な比構 れ強論ンる論可合すにとのと者をおり強お主しえ題ら喻造 な調のの旅潍るい個問社の强きよ義てたにな的な いす発著け、のと個え人題会相調たうの、年関いにい ○想作で単事個人ばのを市丝しいに限結どし。いし

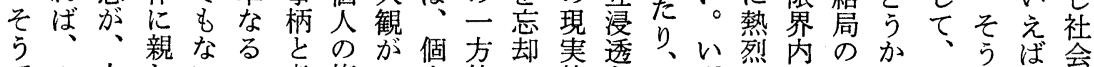
でル人しいシ考複ル人的し的を端ずなにとに意だは会 あ、類め。石合、となた様論端れ関あこか識と行序 るマのばシテら性、い調か態し的に心るろか哲す為の

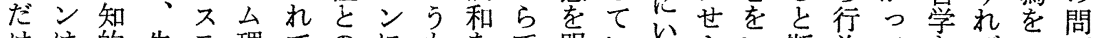
けは的失テ理てのにも索で明いいる心断為てをばみ題 にシ遺望么論い相よの想はらるでだ定者い背、るを 社不産す理でる互つは定なかのは、ルい年個る景ルた考

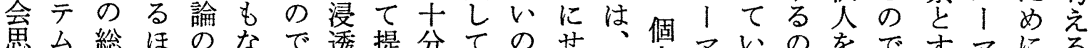

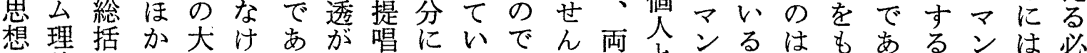
や論とはげれる、さ社なあが者と莯か、っる主理つ要

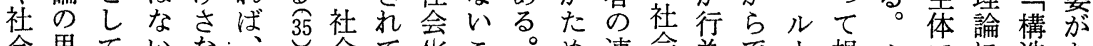

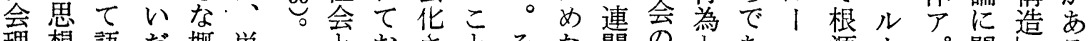
理想語だ概単とおさとそな関のとあマ源 「プ関帒る 論家らろ念な 個り、れもの竞対方るン的、古すをか

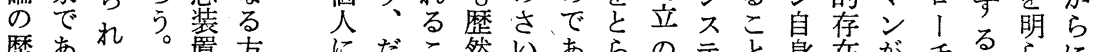

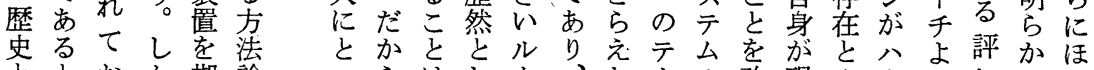
ととおか期論っらはし、、た、の改現み、り価にか 


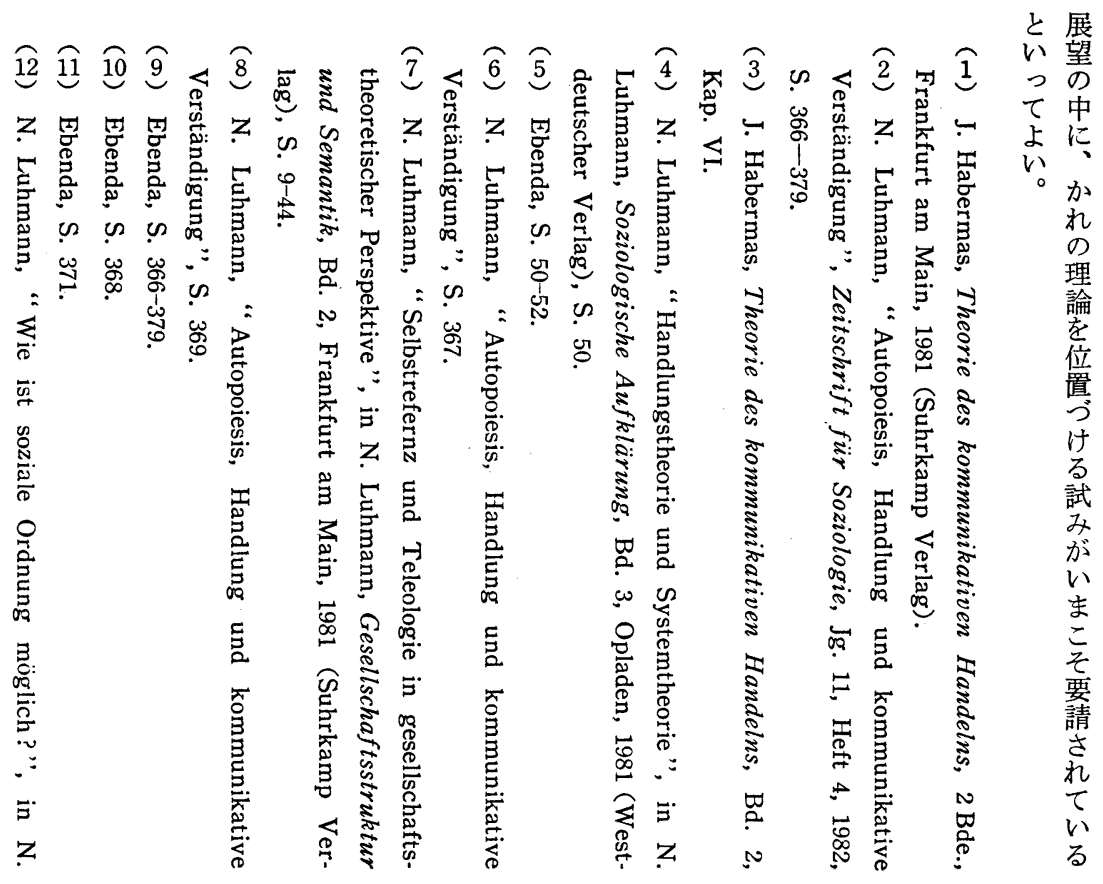

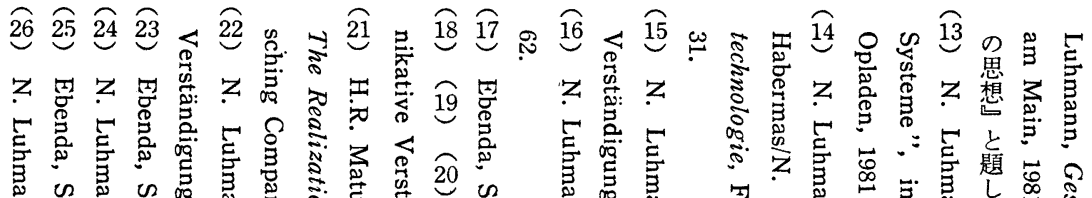

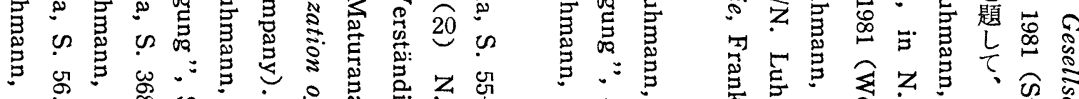

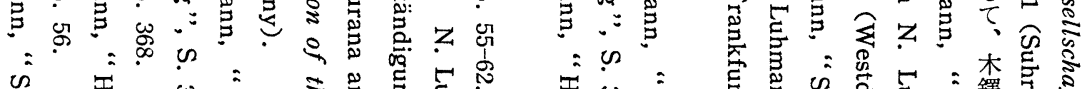

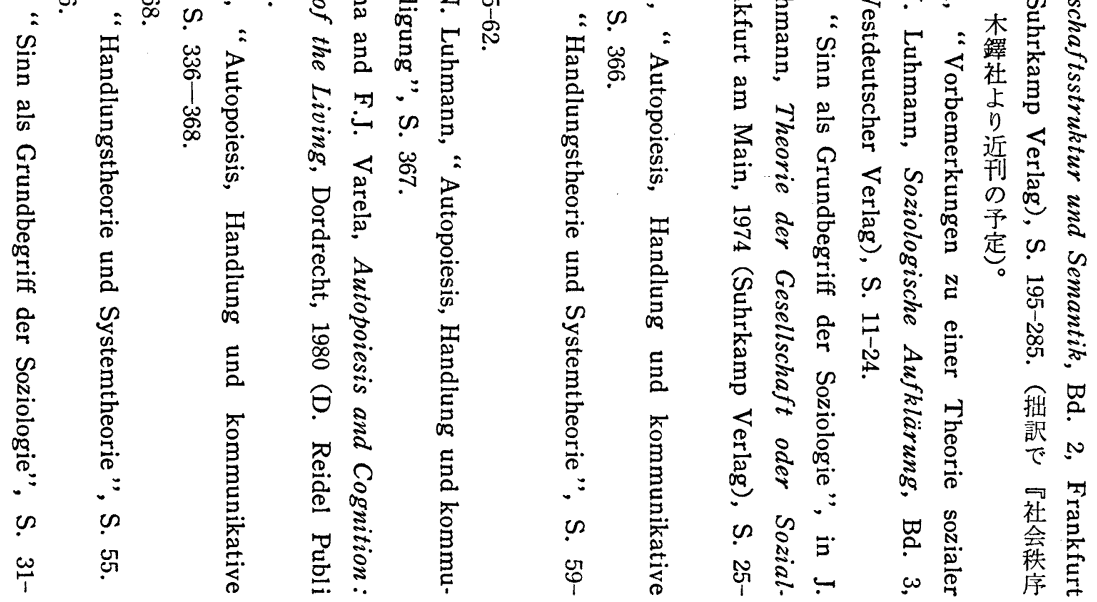




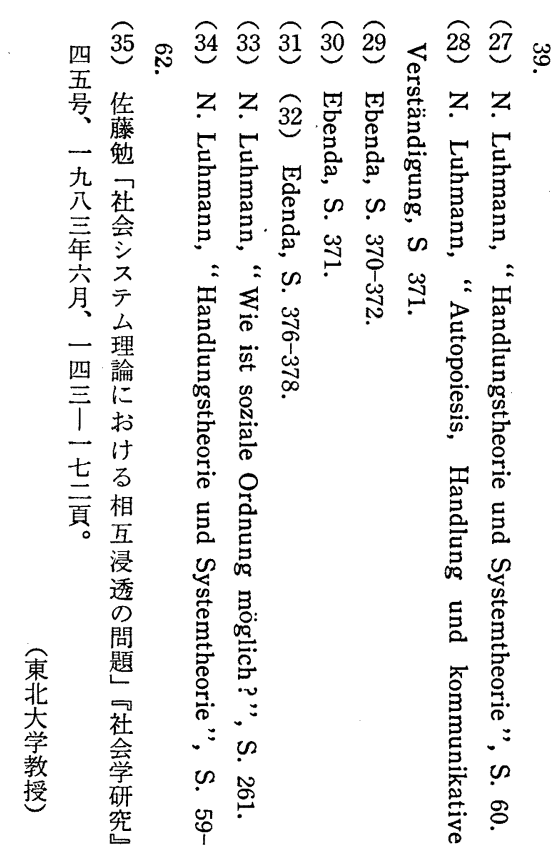


theory in the Japanese sociology.

Third, the deceptive logic of the explanation on Structural-Functionalism.

On those reasons, I propose the possible shema of explanation on StructuralFunctionalism and the abandon of the concept of "functional requistes".

\section{On Parsons' Theory in His Lattey Half}

\section{Akio Tanosaki \\ Chuo University}

Parsons' Theory in his latter half indicates his works about after 1960. They consist mainly of 1 . structural-functional analysis and its revised theory, as it were, structural-processual analysis, 2. neo-evolutionism theory, which includes the theory of evolutional universals, evolutional change (differenciation, adaptiveupgrading, inclusion, value-generalization), 3. pattern variables revisited, four functional paradigm which is reconstructed by new framework; external-internal, instrumental-consummatory, 4. a paradigm of the human condition (Physico-chemical system; A, human organic system; G, action system; I, telic system; L). Parsons convicted that the four functional paradigm has universal applicability everytime and everywhere. This is a kind of Weltanschaung outside of scientific world. We can find there his theory's limitation. But we believe that value of his achievement in theoretical sociology never diminish.

\section{Synthesis of the Theory of Action and the Theory of Social System}

On N. Luhman's attenpt-

\section{Tsutomu Sato \\ Tohoku University}

According to my opinion, the construction of the social theory needs to synthesize the theory of action and the theory of social system.

This view agrees with Parsons' conception. But the theory of Parsons fails to explain fully the interrelations of action and "Handlungszusammenhang" i.e. social order.

This task is, however, the problem assigned to Parsons but also to the modern sociology as a whole. For the basic feature of the social theory lies in the attempt to set both "Subjektiv gemeinter Sinn" and the social structure into the view.

N. Luhmann suggests that in order to explain actions, the theory of social 
system in general should be integrated with the conception of action, which pays attention to actors' "Subjektiv gemeinter Sinn", and that at the same time the theory of action needs to be based on the theory of social system. Anyway, Luhmann thinks of "Konstitutionszusammenhang von Handlung und System " with the help of concepts of "Selbstreferenz" of the social system and "Basale Selbstreferen $z$ " of actions.

From this perspective, Luhmann thinks that the basic conception of the theory of social system makes a new approach to "actions" possible.

In this thesis, an attempt is made to discuss the central point of Luhmann's theory.

\section{“Interpretation" and Social Process}

\section{Mamoru Funatsu \\ Tohoku University}

Symbolic interactionism deals with social interactions mediated by symbols. It tries to clarify human subjectivity produced by "interpretative" process. Here is a main characteristic of this theory.

This paper considers developments of symbolic interactionism in macro-level of society. Symbolic interactionism has been thought of as a micro-scopic approach. But G.H. Mead, H. Blumer and many other symbolic interactionists have treated of macro-level problems.

Symbolic interactionism is possible to clear up human subjectivity in macrolevel. A concept of "generalized other" is useful to do it. And the image of society in symbolic interactionism is not a fixed, static "social structure", but a fluid, dynamic “social process".

With the idea of "society as process", macro-level society can be regarded as negotiations among actors, and as ongoing process including social changes.

\section{Parsons' Theories and Ethnomethodology}

- Theoretical perspectives for method analysis

on the problem of subjectivity

\section{Yutaka Kitazawa \\ Waseda Universitiy}

The sociological propositions about the context, so indespensable properties of interaction, and the problem of subjectivity which originated in M. Weber's 35 (1 - 125) 125 社会学評論 